\title{
Yeni Medya ve Z Kuşă̆ı İlişkisi Bă̆lamında Youtube Kids Uygulamasının İçeriksel Analizi
}

\section{Content Analysis Of Youtube Kids Application In The Context Of New Media And Generation Z Relationship}

\author{
Ali Murat Kırık, ${ }^{\mathrm{a}^{*}}$ Ersin Altun ${ }^{\mathrm{b}}$ \\ ${ }^{a}$ Doç .Dr., Marmara Üniversitesi, İletişim Fakültesi, Eğitim Mh. MÜ Göztepe Yerleşkesi Göztepe, Kadıköy/İstanbul \\ ORCID: 0000-0002-5771-4843 \\ bDoktora Öğrencisi, Marmara Üniversitesi, Sosyal Bilimler Enstitüsü, Eğitim Mh. MÜ Göztepe Yerleşkesi Göztepe, Kadıköy/İstanbul \\ ORCID: 0000-0003-3013-2197
}

\section{MAKALE BİLGİSI}

Makale Geçmişi:

Başvuru tarihi: 12 Şubat 2019

Düzeltme tarihi: 15 Nisan 2019

Kabul tarihi: 24 Nisan 2019

\section{Anahtar Kelimeler:}

YouTube Kids

Z Kuşağı

Yeni Medya

Çocuk

Web 2.0

\section{A R TICLE INFO}

Article history:

Received 12 February 2019

Received in revised form 15 April 2019

Accepted 24 April 2019

Keywords:

YouTube Kids

Generation Z

New Media

Child

Web 2.0
ÖZ

Yeni iletişim teknolojilerinin gelişim göstermesiyle birlikte meydana gelen dijital devrim her alanda etkisini hissettirmiştir. Bu dönüşüm neticesinde kuşaklar arası farklar daha derinden hissedilmeye başlamıştır. Özellikle sosyal ağlara yoğun ilgi gösteren Z Kuşağı'nın video paylaşım sitelerindeki oranı da oldukça yüksektir. Ancak video paylaşım sitelerinde var olan zararlı içerikli unsurlar özellikle çocukların zihinsel ve fiziksel gelişimlerini olumsuz yönde etkilemekte, ebeveyn kontrolünün gerçekleşememesine neden olmaktadır. Bu sorunları çözebilmek adına Google tarafından YouTube Kids isimli bir uygulama geliştirilmiştir. Bu çalışmada YouTube Kids uygulamasına yönelik içerik analizi gerçekleştirilmiş ve üç farklı kanaldan seçilen üç video detaylı bir şekilde irdelenmiştir. YouTubeKids'in yeni medya kapsamında etkili bir uygulama olacağı ve çocukların gelişiminde önemli bir rol oynayacağı sonucu elde edilen bulgular neticesinde ortaya çıkmıştır.

\section{A B S T R A C T}

The digital revolution that took place as a result of the advances in the new communication technologies has influenced almost every area of life. As a consequence of this transformation the differences between the generations became more apparent. Being particularly enthusiastic about the social networks, the Generation $\mathrm{Z}$ uses the video sharing sites intensely. However, harmful content on these platforms have a negative influence especially on the mental and physical development of children and parental control is not really possible. In order to solve these problems an application called YouTube Kids was developed by Google. In this study, a content analysis of three videos selected from three different channels on YouTube Kids was conducted. The results showed that YouTube Kids will be an influential application as a part of the new media and it will play an important role in the development of children.

\section{Giriş}

İletişim, insan hayatının merkezinde yer almaktadır. Mağara duvarlarına çizilen figürlerden duyguların yazınsal dilde ifade edilmesini sağlayan emojilere dek akan süre zarfi boyunca insanoğlu birbiriyle iletişime geçme çabası içerisinde bulunmuştur. Bu çaba her geçen gün farklı boyutlara ulaşmış ve gelişen teknolojiyle birlikte yapısal bir dönüşüm yaşanmaya başlamıştır. Bu dönüşümün elbette ki başlıca mimarı internet teknolojisi olmuştur.

1960'lı yıllarda Amerika Bileşik Devletleri Savunma Bakanlığı bünyesinde yer alan ARPA (Gelişmiş Savunma Araştırmaları Projeleri Birimi) bünyesinde geliştirilen internet teknolojisinin temeli günümüzde DSL teknolojisinin

\footnotetext{
* Sorumlu yazar/Corresponding author
} e-posta: murat.kirik@marmara.edu.tr 
varlığıyla birlikte kapsamlı bir yapıya ulaşmıștır. Çağımızda internet, iletişimin olmazsa olmazı durumuna gelmiştir. Birçok sistem internete entegre bir şekilde çalışmakta, resmi kurum ve kuruluşlar bile işlemlerini internet teknolojisi üzerinden gerçekleştirmektedir. Kanadalı iletişism bilimci McLuhan, dünyanın global bir köye dönüşeceğini o yıllarda ortaya atmıştır. Elektronik iletişimin önemini vurgulayan McLuhan, teknolojik determinizm adı verilen bir kavramdan bahsetmiştir. Nitekim teknoloji artık belirleyici bir durumdadır. Sosyal, siyasal, ekonomik birçok gelişmenin tabanında teknolojik determinizm olgusu yer almaktadır. Tam bu noktada interneti göz ardı edebilmek mümkün değildir.

Geçmişte hesap makinesi sayılabilecek niteliklere sahip olan bugün ise teknolojinin yap1 taşı durumuna gelen bilgisayar teknolojisi ise iletişimdeki dönüşümün başlıca mimarları arasında sayılmaktadır. İnternet ve bilgisayar teknolojisinin etkileşimiyle birlikte zaman ve mekan kavramı giderek kaybolmaya ve boyut değiştirmeye başlamıştır. Pasif izleyici yerini aktif kullanıcılara bırakmış ve izleme alışkanlıkları da hızlı bir dönüşüm içerisine girmiştir. 2000'li yıllarla birlikte internet teknolojisinin maliyetlerindeki düşüş kullanım alanının yaygınlaşmasını sağlamış ve içerikler giderek zenginleşmiştir (Yegen, 2018: 107). Zenginleşen içerikler kullanıcılara farklı alternatifler sunmuş ve yayın yelpazesi genişlemiştir. Her yaştan her kesimden izleyiciye internet ortamından ulaşabilmek mümkündür.

Web 2.0 teknolojisi adı verilen etkileşimli web ile birlikte yayıncılığın çehresi de değişmeye başlamıştır. Video paylaşım sitelerinin varlığı kullanıcıları birer yayıncı durumuna getirmiştir. Kullanıcılar YouTube, Vimeo, DailyMotion gibi video paylaşım siteleri aracılığıyla dosya yüklemesi sağlayabilmekte ve böylece içerik aktarımı gerçekleştirebilmektedir. Video paylaşım sitelerinin günümüzdeki halini almasına Web 2.0 teknolojisinin önemi son derece büyüktür. Çünkü bu ortamlarda etkileşim olgusu ön plana çıktığından dolayı izleyiciler de aktif bir sürece dahil olmaktadırlar. İnternet maliyetlerinin düşmesi, 3G, 4,5G teknolojilerinin varlığı da video izlenme sürelerini arttırmıştır. Kullanıcılar anahtar kelimeler aracılı̆̆ılyla ilgili içeriklere ulaşabilmekte, alternatif videolara erişim sağlayabilmektedirler.

Video paylaşım ağlarının günümüzdeki ölçüde ön plana çıkmasını sağlayan bir diğer etmen ise Facebook, Twitter... vb. gibi sosyal paylaşım ağlarıdır. Çünkü kullanıcılar tarafindan içerikler bu ağlarda paylaşılabilmekte ve daha geniş bir kitleye ulaşım sağlanabilmektedir. Kullanıcılar bu sayede birbirinden farklı içeriklere ulaşabilmekte ve böylece daha zengin bir yapı ortaya çıkmaktadır. Yeni medya doğası gereği kullanıcıları hem üretici hem de tüketici duruma dönüştürmektedir. Buradan işaretle Toffler'ın (1980: 21-31) üre-tüketici kavramını hatırlamak yerinde olacaktır. Çünkü kullanıcılar ana akım medyada yer almayan içeriklere sosyal ağlardan ulaşabilmekte ve geleneksel medyanın yüksek maliyetine karşın yeni medya katılım gücünü arttırmaktadır. Video paylaşım sitelerinde hemen hemen her türden içeriğe ulaşabilmek mümkündür. Bu nedenle geleneksel medyaya oranla bir adım önde yer almaktadır. Yeni medyada maliyet sorunu minimum düzeydedir. Farklı kitlelerin temsili ise maksimum seviyededir.
Yeni medya ile birlikte dijital dünya vatandaşlığı adı verilen bir kavram da ortaya çıkmıştır. Bu kavram her geçen gün etkisini arttırmakta ve bireysel dönüşüme neden olmaktadır. Yeni medyada her yaştan her kesimden birey temsil edilebilmektedir. Tam bu noktada çocuklara ayrı bir parantez açmak gerekmektedir. Dijital yerli ve dijital göçmen tartışmaları gerek Türkiye'de, gerekse de dünyada tüm hızıyla devam etmektedir. Dijital yerliler yeni medyayı daha kapsamlı bir şekilde kullanmaktadırlar. Teknolojinin en parlak dönemlerinde hayata merhaba diyen dijital göçmenler için akıllı telefonlar, tabletler, bilgisayarlar vazgeçilmez durumundadir.

Kuşak farklılıkları yeni medyada da giderek etkisini hissettirmektedir. Özellikle Z kuşağına ayrı bir parantez açmak gerekmektedir. Küreselleşme ve aşırı bireyselleşmenin derinlemesine bir şekilde hissedildiği bir kuşak olan $\mathrm{Z}$ nesli 2001 ve sonrası doğanları kapsamaktadır. Onlar için sokak oyunları tarih olmuş, sanal parklar bu neslin vazgeçilmez mekânları halini almıştır. Z kuşağı için teknoloji ve dijital medya olmazsa olmaz durumuna gelmiştir. Ancak bu nesil internette video izlemeyi seven, hatta kendi videolarını oluşturabilen bir yapıya sahiptir (Duygulu, 2018: 639). Özellikle çocuklar teknolojik anlamda kendilerini geliştirebilen ve sanal ortamda araştırmayı bilen niteliklere sahiptir. Çocuklar için YouTube, gerek çizgi film ve gerekse de eğlenceli videolar seyredebilecekleri sanal bir eğlence ortamidir.

Çocuklar, YouTube gibi video paylaşım sitelerinde birbirinden farklı, hatta onları tehdit eden içeriklere de maruz kalabilmektedirler. Özellikle ebeveynlerin bu noktadaki bilinçsizlikleri önüne geçilmeyecek sorunlara adeta zemin hazırlamaktadır. Günümüzde çocuk kavramının da değişim yaşadığını söyleyebilmek mümkündür. Çocuğun dijitalleştiğini belirten araştırmacılar enformatik çocuğun köleleştiğinin altını çizmektedir. Şirin (1999: 48); "teknolojinin imkânları ile yetiştirilmiş bir varlıktır. Başka bir deyişle modern sömürge... Yani ilkel toplumlarda prangalı çocuğun, modern toplumlarda tasmalı çocukla yer değiştirmesi. Enformatik çocuk, teknolojinin şaşırtıcı imkânlarını kullanan çağdaş bir köleden farksızdır." diyerek bu görüşü tabiri caizse tasdiklemektedir.

Çocuklar geleceğin gençleri olarak çok önemli bir konumda yer almaktadırlar. Ülkelerin teminatı durumunda olan çocukların doğru bir şekilde eğitilmesi ve zararlı içeriklerden uzak tutulması oldukça önemlidir. Özellikle video paylaşım sitelerinden bu tarz zararlı içerikleri görebilmek mümkündür. Daha küçük yaşlarla zararlı içeriklere maruz kalan çocukların gerek fiziksel, gerekse de zihinsel olarak sorunlar yaşayabilmekte ve gelecekte psikolojik sorunlarla karşı karşıya kalabilmektedir. $\mathrm{Bu}$ nedenle günümüz itibariyle dünyanın en çok tercih edilen video paylaşım sitesi YouTube bu sorunun ortadan kalkması ve çocukların zihinsel ve fiziksel gelişiminin zedelenmemesi adına Youtube Kids projesini geliştirmiştir (Tan, L vd., 2018: 282-284). Bu proje çocuklar açısından son derece önemlidir. Çünkü yetişkinler kadar çocuklar açısından da internet önemli bir teknoloji durumundadır.

Bilindiği üzere YouTube'nin genel içeriği düşünüldüğü zaman; aileleri endişeye sokacak içeriklerin var olduğu 
görülmektedir (Kara, 2018). Argo, küfür ve cinsel içerikler büyük bir sorun olarak ortaya çıkmaktadır. Bu ve benzeri sorunları çözmek isteyen YouTube, YouTube Kids uygulamasını geliştirerek çocuk kullanıcılara, gösteri; müzik; öğrenme ve keşfetme amaçlı videoları farklı kategorilerde sunmaktadır. $\mathrm{Bu}$ çalışmada YouTube Kids projesi farklı açılardan irdelenmiş ve uygulamanın içeriği örnek videolar eşliğinde analiz edilmeye çalışılmıştır.

\section{Yeni Medya ile Meydana Gelen Dönüşüm}

Bilgi ve iletişim teknolojilerinde meydana gelen önemli gelişmeler birçok alanda etkisini derinden hissettirmiş ve insan hayatını giderek kolaylaştırmıştır. Bilgisayar, internet ve sayısal teknolojilerin bileşkesi yepyeni bir kavramın doğmasını sağlamıştır. Yeni medya adı verilen bu kavram ekonomi, siyaset, sanat gibi birçok alanda kendisini göstermiştir. Böylece iletişim dünyası yeniden biçimlenmeye başlamıştır.

Özellikle serbest piyasa ekonomisinin varlığı bilgi-işlem teknolojisinin çok daha geniş kitlelere ulaşmasını sağlamış, gündelik yaşam baştan aşağı değişikliğe uğramıştır. Özellikle IBM ve Apple gibi şirketlerin başını çektiği çalışmalarla bilgisayarların maliyetleri düşmüş ve satışları artmıştır. Böylece tüm dünyayı etkileyen teknolojik bir dönüşüm yaşanmıştır (Barbier ve Lavenir, 2001: 346). Bilgisayar ve enformasyon teknolojileri ile bir araya gelen bilginin dijital biçime taşınıp iletildiği yeni nesil iletişim teknolojilerinin bütününü kapsayan bir kavram olan yeni medya mesaj1, içeriği kolay ve hızlı bir şekilde iletebilme imkânına sahiptir. Yeni medya ve geleneksel medya arasında bir takım farklar bulunmaktadır. Geleneksel medya kapsamında basın, radyo, televizyon, sinema... vb. kitle iletişim araçları yer alırken, ak1llı telefonlar, internet, uydu teknolojileri, bilgisayarlar, CD, DVD'ler... ise yeni medya bünyesinde bulunmaktadır. Yeni medyada etkileşim olgusu ön planda yer almaktadır. Ses, metin ve görüntüler dijital ortamda bulunmakta ve erişim oldukça kolay bir şekilde sağlanmaktadır. Geleneksel kitle iletişim araçlarında ise etkileşim söz konusu değildir. Geleneksel medyada aynı mesaja maruz kalan insanlar pasif bir durumda yer almaktadirlar. Ancak yeni medya kullanıcıları aktif bir sürece dâhil etmektedir. Yeni medyanın en temel özelliği etkileşimdir. Diğer özellikler ise kitlesizleştirme ve eş zamansızlıktır. Bu iki özellik birbiriyle bağlantılıdır. Çünkü kullanıcılar iletişim sürecini diledikleri an başlatabilme ve bitirebilme olanağına sahiptir. Kullanıcılar sadece mekânda değil, zaman üzerinde de denetime sahiptirler (Şahin ve Şahin, 2016: 52). Bu denetim kullanıcıların özgür bir yapıya ulaşmasını sağlamaktadır.

Yeni medya gündelik hayatın merkezinde yer almaya başlamış, kültürel, toplumsal, ekonomik ve siyasal yaşamın gelişimi üzerinde önemli rol oynamıştır. Dünya genelinde yeni iletişim teknolojilerinin bu etkin gücünün farkına varılmıştır. Yeni iletişim teknolojileri örgütlenmeyi de beraberinde getirmekte ve teknolojik dönüşümün gerçekleşmesine zemin hazırlamaktadır. Enzensberger; "yeni medya teknolojilerinin yapıları gereği eşitlikçi olduğunu, dolayısı ile bilgiye herkesin eşit olarak ulaşabildiğini, bunun sonucunda da burjuva entelijensiyasının kültürel tekelinin sona ereceğini" ileri sürmektedir. Yeni medyanın aynı zamanda toplumsal bir boyutu da bulunmaktadır. Çünkü ana akım medyada yer almayan içerikler yeni medya aracılığıyla kitleye sunulabilmekledir. Dolayısıyla yeni medyayı alternatif medya olarak da nitelendirebilmek mümkündür. İnternet teknolojisinin gelişim göstermesi ve yaygınlaşmasıyla birlikte üst seviyede enformasyon akışı sağlanmaya başlamış, sosyal paylaşım ağlarının etkisiyle birlikte zaman ve mekân kavramı giderek farklı boyutlara ulaşmıştır (Türk, 2013: 55). Bireysel ve toplumsal hayat yapı bozumu meydana gelmiştir.

Yeni medyaya yönelik birbirinden farklı tanımlar yapılmaktadır. En genel geçer tanım; internet teknolojisiyle birlikte bilgiye erişimde hız, kolaylık ve farklı iletişim yollarının meydana gelmesidir. Ancak yeni medyayı sadece bu şekilde nitelendirmek yavan olacaktır. Yeni medya bilginin dağıtılması noktasında oldukça etkilidir. Kullanıcının aktif hale gelmesiyle birlikte eski iletişim araçlarının boyut değiştirmesi yeni medyayı oluşturmaktadır. Çünkü yeni medya geleneksel medya üzerine inşa edilen bir yapıya sahiptir. Yeni medyanın kapsamı dâhilinde elektronik kitaplar, internet gazeteleri, dijital olarak üretilen filmler örnek verilebilmektedir. Özellikle 15. Yüzyılda Gutenberg'in matbaayı icat etmesiyle birlikte 19. Yüzyılda fotoğraf teknolojisinin gelişim göstermesi yeni medyanın daha kapsamlı bir hal almasını sağlamış ve aktif bir süreç başlamıştır. Yeni medya kendine özgü bir kültür oluşturmakta ve eski kültürün yerini de almaktadır (Bulunmaz, 2014: 25). Bu noktadan işaretle yeni medya ile eski medyanın bağı açık bir şekilde ortaya çıkmaktadır.

Yeni medya kavramına eleştirel bir bakış açısıyla da yaklaşmak gerekmektedir. Yeni medyayı zamana indirgeyen kuramcılar da bulunmaktadır. Bu anlayışa göre geleneksel medya ürünleri de ortaya çıktıkları dönemde yeni medya aracı olarak nitelendirilmektedir. Örnek vermek gerekirse; gazete, radyo, televizyon gibi kitle iletişim araçları icat edildikleri dönem göz önünde bulundurulduğunda oldukça ilgi çekmiş ve bu araçlar insanların yoğun talebine sahne olmuştur. Tarihsel süreç genel olarak değerlendirildiği vakit hemen hemen her buluş zamanla gelenekselleşmektedir. Burada zaman kavramı ön planda yer almaktadır. Kısacası dünün yenileri bugünün eskileri haline gelmiştir, yani zamanla gelenekselleşmiştir. Scolari (2009: 945) yeni medyayı zamansal ve kültüre açıdan değerlendirmiştir. Günümüzde yeni medya olarak ifade edilen iletişim araçlarının yarın "eski” bir hal alacağı yapılan araştırmalar neticesinde açık bir şekilde görülmektedir.

Yeni medyanın temelini bilgisayar teknolojisinin oluşturduğunu söyleyebilmek mümkündür. Günümüzde gerek Türkiye'de, gerekse de dünyada bilgisayarlar hayatımızı tamamıyla sarmış durumdadır. Bilgisayar ve internet kullanımının son derece yaygın bir hal almasıyla birlikte yazılım ve donanım adı verilen iki temel unsur ortaya çıkmıştır. Özellikle donanımsal gelişmeler bilgisayarların boyutlarının küçülmesini sağlamış, veri depolama ve işleme kapasitelerini ise arttırmıştır. Tabii bu durum maliyetlerin de düşmesine temel teşkil etmiştir. Yazılım alanındaki gelişmeler ise kullanım alanını kolaylaştırmıştır. 19501960'lı y1llarda kullanılan büyük ölçekli bilgisayarlar, 1980'li yıllarda herkesin kullanabildiği masaüstü bilgisayarlara dönüşmüştür. Masaüstü bilgisayarlar ise günümüzde yerlerini dizüstü bilgisayar ve tabletlere bırakmıştır (Yüksel, 2014:7- 
8). Teknolojik dönüşüm ise bilgisayarların yerini akıllı telefonların almasını sağlamıştır. Akıllı telefonlar hemen hemen bir bilgisayarın yapabileceği her türlü işlemi gerçekleştirebilecek potansiyele sahiptir. İnternet tabanlı depolama ve holografik görüntüler de yeni medyanın bireylere kazanımları arasında yer almaktadır.

Yeni medyanın dönüşümünü sağlayan bir diğer önemli etmen ise sayısal teknolojidir. Çünkü sayısal teknoloji de bilgisayar teknolojisi kadar önemli bir yapıya sahiptir. Bilgi, iletişim ve medya sektörünü günümüzdeki ölçüde yöndeştiren ve neredeyse iç içe sokan sayısal teknolojinin önemi de yadsınamaz derecede büyüktür. Özellikle sayısal sıkıştırma standartları aracılığıyla yerden büyük ölçüde kazanım sağlanmış ve depolama sistemlerinde dönüşümler meydana gelmiştir. Sayısal teknoloji ses, görüntü, metin, resim, hareketli içerik, video... vb. biçimindeki her türlü içeriğin bilgisayar diline ve teknolojisine dönüştürülmesi olarak ifade edilebilmektedir. "Sayısal teknoloji bu içeriklerin elektronik ortamlarda üretimi, işlenmesi, düzenlenmesi, aktarllmasi ve saklanması gibi işlemleri önceki analog döneme göre klyaslanmayacak ölçüde hızlı ve güçlü bir işlem yeteneği ile yapmaktadır"' (Törenli, 2005: 98). Yeni medya ses, görüntü, metin gibi birçok farklı veri çeşidini sayısal ortamda bir arada sunabilme özelliğine sahiptir. $\mathrm{Bu}$ nedenle multimedya biçimselliği taşımaktadır.

Yeni medya aracılığıyla birbirinden farklı bilgi ve mesajlar kilometrelerce ötede yer alan çok sayıda kullanıcıya gönderilebilmekte, bu gönderilenler paylaşılabilmekte ve karşılıklı alışveriş sağlanabilmektedir. Aynı zamanda bilgi ve ileti işlenebilmekte, tekrardan düzenlenebilmekte, değiştirilebilmekte ve bu sayede kişiselleştirilerek yeni koşullar altında yer alabilmektedir. Burada işaretle yeni medyanın kullanıcı kontrolünde olduğunu söylemek çok doğru olacaktır.

\section{Bir Video Paylaşım Sitesi Olarak YouTube}

Günümüzde yaşanan teknolojik gelişmelerin neticesi itibariyle dijitalleşme süreci başlamış ve internet kullanımı küresel bir hal almıştır. Nitekim dijitalleşme sürecinin ve internet kullanımının hızlıca artış göstermesi yeni alanlara, yeni alışkanlıklara, yeni mesleklere, yeni mecralara, yeni olanaklara vb. pek çok yenileşme süreçlerine imkan sağlamıştır. Bu ortamın hazırlanmasında yeni medyanın kazandırmış olduğu etkileşim, kitlesizleştirme ve eşzamansızlık özellikleri etkili olmuştur. Nitekim iletişim ve haberleşme aksiyonları bambaşka bir boyuta evrilmiş, bu durum dijital teknoloji kullanıcı sayısının her geçen gün artışına zemin hazırlamıştır.

Geleneksel medyanın edilgen yapısı bireyleri salt tüketen konumda standardize etmektedir. Böylelikle tüm gözler bir noktada toplanmakta ve olay veya olgulara karşı istendik yönde izlenim oluşturulabilmektedir. Yeni medya akımıyla gündelik hayata entegre edilen sosyal paylaşım ağları ise bu yapıyı kırmaya başlamıştır. Düşünce ve fikirlerini sosyal paylaşım ağları üzerinden dile getirmeye başlayan bireyler, edilgen yapının pasifliğinden sıyrılarak üreten ve etkin bireyler haline gelmiştir. Böylece bireyler sosyal ağlar üzerinden paylaşım ve etkileşim alanları yaratarak, kamusal alanın dijitalleşmesine katkı sağlamıştır. Bu süreçte etkileşim olgusu ön plana çıkmaktadır. Yeni medyanın sağlamış olduğu özelliklerden biri olan etkileşim olgusu ile tek taraflı iletişimden sıyrılarak, bireylerin kendi özgün içeriklerini üretebilmelerini sağlayan medya teknolojisine erişilmiştir. Özellikle video teknolojisi bağlamında yeni medya niteliklerinin daha fazla ön plana çıktığı görülmektedir. Bunun nedeni ise sosyal medya kanallarının özgürce içerikler üretmeye imkan veren teknolojik yapısıdır. Böylece bireyler iletişim süreçlerine doğrudan katılım sağlama imkanı elde etmiştir.

Günümüzde Facebook, Instagram, Twitter, YouTube gibi pek çok popüler sosyal medya kanalı faaliyet göstermektedir. Bu kanallar arasında video teknolojisine doğrudan imkan veren ise şüphesiz YouTube platformu olmuştur. 15 Şubat 2005 yılında 3 eski PayPal çalışanı tarafından kurulan YouTube, görmüş olduğu kitlesel ilgi neticesinde 2006 yılında Google tarafından satın alınmıştır (Ying, 2007: 17-18). Kullanıcılarına kendi kanallarını oluşturabilme, video izleme, videoları farklı sosyal paylaşım sitelerinde paylaşabilme, içerik üretme ve paylaşma olanağı sunan YouTube, hayata dair her türlü duruma özgü içeriklerin sunumuna imkan sağlamaktadır. Bunun yanı sıra eğitim ve güncel içeriklerin aktarımında da aktif rol oynamaktadır. YouTube'nin makro düzeyde genişleyerek devam eden kullanıcı sayısı oldukça aktüeldir. Platform üzerinden her yaştan kesim ilgi alanlarına göre içerikler bulabilmekte, amatör ve profesyonel kişilerin içerikler üreterek etkileşime geçme firsatı yakalayabilmektedir (Mutlu, 2017: 27).

YouTube platformu salt video görüntüleme ve paylaşma aksiyonlarından ibaret değildir. 'Kendinizi Yayınlayın (Broadcast Yourself)' sloganıyla hareket eden YouTube, içerik üretme özelliği ön planda olmak üzere iletişim ve paylaşım işlevleri üzerine faaliyetler göstermektedir. Bireylerin üretim ve tüketim süreçlerinde aktif rol oynadığı bu platformda üretilen içerikler diğer sosyal paylaşım ağlarında da paylaşıma sunulabilmekte veya video içeriklerinin altına yorumlar yapılabilmektedir. Böylece YouTube, video görüntüleme işlevinin yanı sıra paylaşım alanı işlevi de görmektedir. Bu paylaşım pratikleri ise yeni bağlantılar kurmada ve sosyal ağların gelişiminde önemli rol oynamaktadır (Jarvis, 2012: 203).

Sosyal paylaşım ağları üzerinden yapılan iletişim neticesinde sosyal topluluklar oluşmaktadır. $\mathrm{Bu}$ toplulukların oluşumunda ise ortak bir sosyal medya dilinin kullanımı ve video paylaşımlarının etkisi oldukça yüksektir. Kullanıcıların videoların altına yorumlar yapabilmesi, YouTube sistemine kayıt olarak kanal oluşturulabilmesi, paylaşımlarını beğendikleri diğer kullanıcıların takip edilebilmesi ve beğenilen videoların paylaşımlarının yapılabilmesi sosyal topluluğu besleyen pratiklerdir. Nitekim bu pratikler YouTube platformuna dijital yayın alanı olmanın yanı sıra sosyal paylaşım alanı niteliği de kazandırmaktadır.

Sosyal paylaşım ağı olarak YouTube her yaştan her kesime hitap etmekte, kaynağın alıcıya ve alıcının kaynağa dönüşümüne imkan vererek etkileşim olanağı sağlamaktadır. $\mathrm{Bu}$ bağlamda etik kurallar ve telif hakları doğrultusunda pek çok içerik üretilmekte, gizlilik ayarlarıyla videolar istenen zamanda istenen kişiler tarafından görüntülenebilmektedir. Teknolojik gelişmeler neticesinde ortaya çıkan taşınabilir 
iletișim araçları ve mobil internet teknolojisinin insan yaşamının bir parçası haline gelmesiyle birlikte video görüntüleme ve içerik paylaşımı aksiyonları, zaman ve mekana bağımlı kalmaksızın sağlanabilir duruma gelmiştir (Dondurucu \& Uluçay, 2015: 880).

Popüler paylaşım ağı olan YouTube'nin özelliklerine bakacak olursak şu şekilde bir liste oluşturabiliriz (Alper, 2012: 115):

- Kullanıcılarına kendi yayınlarını yapma imkânı vermesi,

- Platforma yüklenen videoların küresel boyutta görünürlük sağlaması,

- Kullanıcılar arasında iletişim ve haberleşme imkânı sağlaması,

- Videoları kategorileştirerek, ilgi alanlarına uygun videolar bulunmasına olanak sağlaması,

- Boz zamanın değerlendirilmesi neticesinde kullanıcıların vakitlerini eğlenceli bir şekilde geçirmelerini sağlaması,

- Eğlence ihtiyacının yanı sıra eğitsel ihtiyaçların karşılanmasına da imkân sağlaması,

- Yeni kültürleri ve yaşam tarzlarını tanıtmaya imkân vermek,

- Paylaşılan videoların altına düşünce, görüş ve yorumların aktarılmasına imkan vererek, kullanıcıların eleştirel yönlerini güçlendirmesi ve tartışma ortamlarına olanak sağlaması

Yeni medya akımıyla hayatımıza dâhil olan ve bugün milyonlarca kullanıcı sayısıyla faaliyet göstermeye devam eden YouTube, içerik uygulamaları ve sahip olduğu özellikler neticesinde video paylaşım ağlarına yönelik akademik çalışmalarda önemli bir kılavuz işlevi görmektedir. Bu çalışmada ise YouTube'nin her geçen gün artış gösteren kullanıcı skalasında çocuk yaş grubu ele alınacak ve bu yaş grubuna yönelik üretilen uygulamalar incelenecektir.

\section{Z Kuşağının Yeni Medya Karşısındaki Durumu}

Teknolojinin her geçen gün gelişmesiyle beraber bireylerin kullanımlar ve doyumları da değişkenlik göstermeye başlamıştır. Dönemin teknolojik imkânlarına göre şekillenen kullanım olanakları doyum noktalarını da belirlemektedir. $\mathrm{Bu}$ bağlamda iletişim araçlarından beklenen imkanlar ve doyumlar kuşaktan kuşağa değişmektedir. Bu kuşakları X, Y ve $\mathrm{Z}$ olarak tanımlamak mümkündür. $\mathrm{X}$ kuşağı geleneksel iletişim araçları bağlamında değerlendirilirken; Y kuşağı ise bilgisayarların gündelik hayatın bir parçası haline geldiği ve internet teknolojisiyle tanışmaya başlanıldığı dönemi ifade etmektedir. Z kuşağı ise 2000'li yıllarda doğan ve yeni medya akımına dâhil olan kuşağı temsil etmektedir. Bu kuşaklar arasındaki farklılıklar öğrenme durumu, gündelik hayat pratikleri, hayata bakış, çalışma hayatı, sosyolojik ve psikolojik özellikler, motivasyon ve beklentiler gibi pek çok değişkeni etkilemektedir. Söz konusu kuşaklar arasındaki en belirgin farklılık ise $\mathrm{Y}$ ve $\mathrm{Z}$ kuşakları arasında yaşandığ 1 ifade edilmektedir. $\mathrm{Bu}$ durumun nedeni olarak ise $\mathrm{Y}$ kuşağ bilgisayar ve internet teknolojisine geçiş sürecinde yer almasından dolayı teknolojik gelişmelere hızlı bir şekilde adapte olurken; Z kuşağ ise 2000'li yıllardan sonra yaşanan, teknolojinin yoğun kullanım döneminde doğmasıdır. Bu nedenle iki kuşak arasında belirgin farklılıklar yer almaktadır (Aydemir ve Şentürk, 2016: 657). Kuşakların sahip olduğu karakteristik özellikleri tablo üzerinden özetlemek mümkündür (Göztaş ve Yanık, 2016):

Tablo 1: Koşullar, Kuşaklar ve Genel Karakteristikleri

\begin{tabular}{|c|c|c|c|c|c|}
\hline Şartlar & $\begin{array}{l}\text { Sessiz Kuşak } \\
\text { 1925-1945 }\end{array}$ & $\begin{array}{l}\text { Baby Boomers } \\
\text { Kuşağı 1946- } \\
1964\end{array}$ & X Kuşağı1965-1979 & $\begin{array}{l}\text { Y Kuşağı1980- } \\
2000\end{array}$ & Z Kuşağı2000-2020 \\
\hline $\begin{array}{l}\text { Zamanın Öne } \\
\text { Çıkan Şartları }\end{array}$ & $\begin{array}{l}\text { Savaş, Ekonomik } \\
\text { Krizler ve } \\
\text { YoklukDönemi }\end{array}$ & $\begin{array}{l}\text { Soğuk Savaş, } \\
\text { Küreselleşme ve Aşırı } \\
\text { Rekabet, Yoğun } \\
\text { Üretim, Göreceli Refah }\end{array}$ & $\begin{array}{l}\text { Sosyal Çalkantılar, Ekonomik } \\
\text { Kriz, İşsizlik ve Teknolojiye } \\
\text { Merhaba Dönemi }\end{array}$ & $\begin{array}{l}\text { Teknoloji, } \\
\text { Bilgisayarlaşma, İnternet, } \\
\text { Postmodernizm }\end{array}$ & $\begin{array}{l}\text { İleri Teknoloji, İnternet Sahiplik } \\
\text { Oranı, Yeni Medyalar, Yenilikçilik, } \\
\text { Postmodernizm }\end{array}$ \\
\hline
\end{tabular}

\begin{tabular}{|c|c|c|c|c|c|}
\hline $\begin{array}{l}\text { Çalişma Hayati } \\
\text { Anlayişi }\end{array}$ & $\begin{array}{l}\text { Çalışmak } \\
\text { Yaşamaktır, İşyerine } \\
\text { Adanmış }\end{array}$ & $\begin{array}{l}\text { Çalışmak İçin } \\
\text { Yaşamak, İşyerine } \\
\text { Sadık }\end{array}$ & $\begin{array}{l}\text { Yaşamak İçin Çalışmak, Sadık } \\
\text { Fakat Firsatlara Açık }\end{array}$ & $\begin{array}{l}\text { Çalışmak Yaşamın Bir } \\
\text { Parçasıdır, } \\
\text { İş Değişimine Yatkın }\end{array}$ & $\begin{array}{l}\text { Çalışmak Başarının ve Kaliteli Yaşam } \\
\text { Deneyiminin Aracıdır, } \\
\text { Sadık Değil. Sık İş Değişikliği Yapar }\end{array}$ \\
\hline Otorite Anlayıșı & Otoriteye Bağlı & Otoriteye Sadık & Otoriteye Saygil1 & $\begin{array}{l}\text { Otoriteyi Sorgulayan ve } \\
\text { Dönüştürmek İsteyen }\end{array}$ & Otoriteyle Çatışan \\
\hline $\begin{array}{l}\text { Öne Çıkan } \\
\text { Psikolojik } \\
\text { Özellikler }\end{array}$ & $\begin{array}{l}\text { Hirsl1, Kaygilı ve } \\
\text { Risklerden Kaçınan }\end{array}$ & $\begin{array}{l}\text { Kuralcı, Sabırlı, Lider, } \\
\text { Çalışkan }\end{array}$ & $\begin{array}{l}\text { Şüpheci, Uyumlu ve Kontrollü, } \\
\text { Rekabetçi }\end{array}$ & $\begin{array}{l}\text { Sorgulayıcı, Yenilikçi, } \\
\text { Odaklanma Seviyeleri } \\
\text { Düşük, Özgüvenli, } \\
\text { Yarışmayı Seven, Sosyal } \\
\text { ve Takımla Çalışabilen }\end{array}$ & $\begin{array}{l}\text { Yaratıc1, İnovatif, Çoklu İş Yapabilen, } \\
\text { Yenilikçi, İnteraktif ve Yüksek } \\
\text { Paylaşım Güdüsü Hakim }\end{array}$ \\
\hline $\begin{array}{l}\text { Motivasyon } \\
\text { Kaynaği }\end{array}$ & $\begin{array}{l}\text { Devamlllik ve } \\
\text { Takdir }\end{array}$ & Takdir ve Kariyer & Maddiyat ve Kariyer & $\begin{array}{l}\text { Esneklik, İtibar ve } \\
\text { Kariyer }\end{array}$ & $\begin{array}{l}\text { Esneklik, Değişen İş Tanımları, Özel } \\
\text { Girişim, Sosyal Statü }\end{array}$ \\
\hline
\end{tabular}

(Aydemir ve Şentürk, 2016: 659)

Tablo incelendiğinde Z kuşağının diğer kuşaklara göre farklı bir dinamizme sahip olduğu görülebilmektedir. Özellikle teknoloji odaklı yaşam tarzına sahip olmaları bu dinamizmin temelini oluşturmaktadır. Bu kuşağın anahtarı kelimeleri ise ileri teknolojiler, yeni medya, sürekli çevrimiçi durum, yenilikçi, interaktif ve esneklik olarak ifade edilebilir
(Aydemir ve Şentürk, 2016: 659). Yeni medya akımıyla beraber oluşan teknolojik dönüşümün içinde doğan ve bu hızlı yaşama anında adapte olan Z kuşağının kullanımlar ve doyumları da farklılık göstermektedir. Bu bağlamda sosyal medya kanalları üzerinden oyalanma ve eğlenme faaliyetlerini yürütmekte, kişisel kimliklerini ve rol 
modellerini bu kanallar üzerinden belirlemekte, kişisel ilișkilerini bu kanallar çerçevesinde oluşturmakta ve çevresinde yaşanan olay ve olguları yine sosyal medya kanalları üzerinden takip etmektedir. Ayrıca eğitim modüllerinin de dijitalleşmeye başlamasıyla beraber öğrenim süreçleri de sosyal kanallardan gerçekleşmeye başlamıştır.

Z kuşağının teknoloji ile bütünleşik bir yaşam biçimine sahip olması ve gündelik hayatın her alanına teknolojinin entegre edilmesi avantajların yanında birtakım olumsuzlukları da doğurmaktadır. Bunun nedeni ise sosyal medya kanalları üzerinden üretilen içeriklere erişilebilirliğin kontrolsüz bir şekilde sağlanabiliyor olmasıdır. Bu durum çeşitli dezenformasyonlara, propaganda faaliyetlerine, alg1 ve riza üretimine ve kötü alışkanlıklara yönelik güzellemelere imkan sağlamaktadır. Yakın geçmişte yaşanmış olan ve hala etkisini sürdürün "Mavi Balina" oyunu da bu duruma örnek olarak gösterilebilir. Sosyal medya üzerinden hılı bir şekilde yayılan bu oyun, içeriğinde verdiği direktiflerle yüzlerce çocuğun intihar etmesine neden olmuştur. Bu ve buna benzer pek çok uygulamanın yer aldı $\breve{g}_{1}$ sosyal medya platformlarında Z kuşağını korumaya yönelik önlemler almak kaçınılmaz hale gelmiştir.

İletişim dünyasında yaşanan gelişmeler toplumun her kesiminde önemli etkiler yaratmıştır. Bu etkilerin en yoğun yaşandığı kuşak ise şüphesiz ki $\mathrm{Z}$ kuşağı olmuştur. Bu kuşağın bireyleri olan çocuklar, gelişim çağlarını teknolojiyle iç içe geçirmektedir. Gerek eğitim gerekse de eğlence amaçlı kullanım alanlarıyla doyum yaratan bu yeni teknolojinin önemli unsurlarından biri de sosyal medya platformları olmuştur. Gelişen teknoloji ile birlikte internet dünyasının telefon, tablet gibi ürünler üzerinden mobilize edilmesi internet erişimini ve bu doğrultuda internet kullanımını da artırmıştır. Böylece çocuklar sadece evde değil, istenilen her noktada internete kolayca erişim sağlayabilir duruma gelmiştir. Bu yeni dünyaya hızlıca adapte olan çocuklar için ise pek çok içerik üretimi yapılmıştır.

Günümüzde çocuklar vakitlerinin çoğunu sosyal medya platformları üzerinde geçirmektedir. Çocuklarda oluşan bu medya alışkanlığı küçük yaştan itibaren inşa edilmekte ve sosyal ilişkilerinin dijitalleşmesine neden olmaktır. Her ne kadar sosyal medya platformlarında yaş sınırı olsa da çocuklar arasındaki kullanım oranı oldukça fazladır. Bu platformların pek çoğunda 13 yaş sınırı vardır; ancak bu sınıra bakılmaksızın çocuk yaştaki bireylerin kayıt oranlarının fazla olduğu söylenebilmektedir. Örneğin Avrupa ülkelerinin geneline bakıldığı zaman 9-12 yaş aralığındaki çocukların 5'te 1'nin Facebook hesabı vardır ve bu oran bazı ülkelerde daha artabilmektedir (Livingstone vd., 2012: 1-3). Örnekte belirtilen 9-12 yaş aralığ grubu da aslında esnektir. Genel çerçevede bakıldığı zaman her ne kadar oyun için de olsa 9 yaş altının da sosyal medya platformlarını kullanabildiği gözlemlenebilmektedir.

Sosyal medya kullanımının çocuklar arasında hızlı bir şekilde yaygınlaşmasının olumlu ve olumsuz pek çok yansıması mevcuttur. Olumlu özellikleri arasında medyanın doğru ve ebeveyn kontrolü ile kullanımıyla beraber eğitici bir nitelik olduğunu söylemek mümkündür. Özellikle gelişim çağındaki çocuklara yönelik hazırlanan eğitici içerikler sayesinde pedagojik anlamda birçok yararlı içerik üretimi yapılabilmektedir. Bunun yanı sıra olumsuz içerikler de sosyal medyanın bir gerçeğidir. $\mathrm{Bu}$ olumsuz içerikler gelişme çağındaki çocuklar üzerinde önemli riskler barındırmaktadır. $\mathrm{Bu}$ içeriklerin niteliği cinsellik, şiddet, mahremiyet, kötü alışkanlıklar, argo vb. pek çok olabilir. Bu noktada önemli olan çocukları tüm bu risklerden koruyabilmek ve bilinç inşa edebilmektir. Çünkü gelişim çağındaki çocuklarda henüz yorumlama ve eleştirel bakış unsurları tam olarak gelişmediği için ne görürse onu kapar anlayışı hakimdir.

Tüm bu bilgiler 1şı̆̆ında Z kuşağının yeni medya ile olan bütünleşik ilişkisi, sosyal medya platformlarının söz konusu kuşağa yönelik uygulama ve projelerine yön vermektedir. $\mathrm{Bu}$ uygulamalar aracılığıyla hem Z kuşağının platformu kullanım oranları artırılmaya çalışılmakta hem de gelişimlerini olumlu yönde etkileyecek içerikler sunulmaktadır. Çalışma kapsamında ele alınan YouTube, $\mathrm{Z}$ kuşağına yönelik uygulama politikasında öncülük eden sosyal platformlardan biri olmuştur. Kullanıcılarının büyük çoğunluğu $Z$ kuşağından oluşan YouTube'nin genel içeriğinde ebeveynleri endişelendirecek paylaşımlar bulunmaktadır. $\mathrm{Bu}$ paylaşımlarda sıklıkla argoya, küfre, kötü alışkanlık güzellemelerine, cinselliğe ve daha pek çok olumsuz nitelikte durumlara yer verilmektedir. Bu durumun önüne geçebilmek ve $\mathrm{Z}$ kuşağının kullanımlar doğrultusunda beklediği doyumlara cevap verebilmek adına ise YouTube Kids projesi faaliyete geçirilmiştir. Çalışmanın bundan sonraki bölümünde YouTube Kids projesi farklı açılardan ele alınacak ve uygulamada yer alan içerikler irdelenerek analiz edilmeye çalışılacaktır.

\section{Youtube Kids Uygulamasının İçerik Analizi}

YouTube Kids, dünyanın en çok tıklanan video paylaşım sitesi YouTube'nin çocuklar için geliştirilmiş projesidir (https://kids.youtube.com/, Erişim Tarihi: 23.04.2018). 30 Nisan 2017 tarihi itibariyle yaygın bir duruma gelmiş ve bir uygulama olarak Google Play ve Apple Store'lerdeki yerini almıştır. $\mathrm{Bu}$ uygulamaya erişim ücretsiz bir şekilde gerçekleştirilebilmektedir.

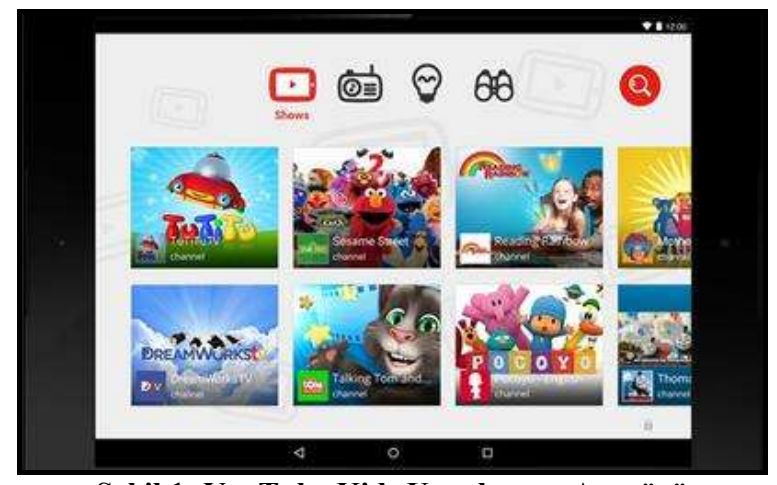

Şekil 1: YouTube Kids Uygulaması Arayüzü

$\mathrm{Bu}$ çalışmada YouTube Kids uygulaması ana hatlarıyla incelenmiş ve bu inceleme gerçekleştirilirken içerik analizi yöntemi kullanılmıştır. İçerik analizi; "metin içinde tanımlanan belirli karakterlerden sistematik ve tarafsız sonuçlar çıkarmak için kullanılan bir araştırma tekniğidir" (Stone vd., 1966: 213). İçerik analizi yönteminde var olan mevcut durum tarafsız ve sistematik bir şekilde ele 
alınmaktadır. Nitekim bu çalıșmada da YouTube Kids uygulaması bu yönteme bağlı kalınarak incelemiş ve bulgular elde edilmeye çalışılmıştır. Çalışma; YouTube Kids bünyesinde yer alan "Sesame Street TV", "TuTiTuTV" ve "DreamWorks TV" kanallarından seçkisiz bir şekilde alınan videolarla sinırlıdır.

Birinci olarak Sesame Street TV kanalında yer alan "Sesame Street: Elmo's World: Play Ball!" videosu incelenmiştir. Bilindiği üzere Susam Sokağı uzun yıllardır çocuklar eğitici bir işlev üstlenmektedir. Yıllar geçse de önemini yitirmemiş bir programdır. Bu programın temel kurgusunda çocukların ilgisini çeken kukla figürü kullanılmakta ve incelenen videoda gerek çocuk sesiyle seslendirmenin yapılması gerekse de arka planda pastel boyayla gayet sade mekan tasarımının oluşturulması direkt olarak çocukların ilgisini çekmeye yönelik üretimlerdir. Bu videoda Elmo karakteri üzerinden top nasıl seker, bir kucağa kaç top sığar, topla hangi oyunlar oynanır, topun hangi spor dallarında kullanıldığına dair sorulara cevap verilmekte ve topun nasıl yakalanabileceğine dair yöntemler öğretilmektedir. Gösterilen videoda palyaço kıyafetli bir adam aracığıyla öncelikle top yakalamadaki yanlış yöntemler gösterilmekte, ardından kuklanın "ellerini kullan" direktifiyle topun yakalanmasına yönelik doğru yöntem belirtilmektedir. Yani doğru yönteme yanlışlar yapılarak, deneyerek ulaşılmaktadır. $\mathrm{Bu}$ önerme çocuk gelişimi için de önem arz etmektedir. İlerleyen akışta ise çocuklar gösterilerek havadan gelen, sekip gelen, yerden gelen topların nasıl yakalanacağı gösterilmektedir. Ardından topun 28 kere ziplamasını sayarak, sayılar da çocuklara öğretilmektedir (bkz. Şekil 2). Ayrıca topun bir cisim olarak fiziksel özelliklerine vurgu yapılarak zıplayabilme ve yüksekten düştüğünde zarar görmeme niteliği üzerinde durulmuştur. Videoda zıplama eyleminin çocuklar tarafından kavranabilmesi için yumurta, pasta ve kitabın yere düştüğünde zarar gördüğünü ve olduğu yerde kaldığını fakat topun yapısı gereği yere temas ile zarar görmeden tekrar havalandığı gösterilmektedir. Farklı biçim ve yapıdaki toplar ekrana getirilerek her spor dalı için ayrı topların kullanıldığı anlatılmaktadır. Bu sayede çocuklar golf, tenis, futbol gibi spor dallarında farklı top çeşitlerinin kullanıldığını da ögrrenmektedir. Videonun sonunda ise daha önce de belirtildiği gibi doğru yöntemi yanlış yaparak, deneyerek öğrenme öğretisini destekleyecek nitelikte içerik oluşturulmuştur. $\mathrm{Bu}$ içerikte ise sahilde babasıyla top oynayan kızın önce topu atmasındaki ve yakalamasındaki başarısızlıkları gösterilmiş, ardından havadan atınca hem yakalamanın hem de karşı tarafa yakalatmanın kolay olacağı aktarılmıştır. Nitekim bu kanalda yer alan birçok videoda eğitici unsurların varlığı açık bir şekilde görülmektedir. Harfler, sayılar ve çocukların sosyalleşebilmeleri adına yapması gerekenler kodlanarak çocuklara sunulmaktadır.

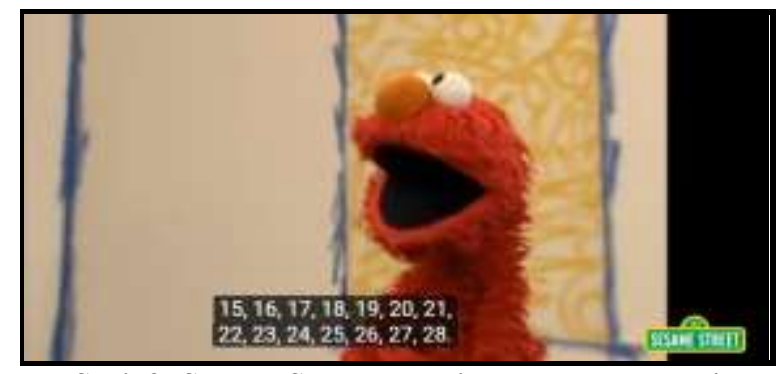

Şekil 2: Sesame Street: Elmo's World: Play Ball!
Çocukların sosyalleşmesini, yaşadıkları çevreyi ve nesneleri kavramasını sağlayan bir diğer önemli kanal ise "TuTiTuTV"dir. "TuTiTuToys | Kitchen" isimli videoda uçan bir araç firın, ocak, dolap, fincanlar, kaşıklar gibi mutfak eşyalarını teker teker yukarıdan aşağıya doğru atmakta ve mutfağı organize etmektedir (bkz. Şekil 3). Öncelikle eşyalar karmaşık bir düzende aşağıya atılmakta ve mutfağın bütünlüğü deneme yanılma yöntemiyle doğru bir şekilde oluşturulmaktadır. İlk videoda olduğu gibi bu videoda da deneme yanılma yöntemiyle, yanlış yapa yapa doğru yolu bulma önermesiyle karşılaşmaktayız. Son olarak tezgâhlar, buzdolabı ve mini firın da yerleştirilir. İki tane sandalye de konduktan sonra pelüş bir ayı tabureye oturur ve yukarıdan çay fincanları iner. Çaydanlık ocağa gider ve mutfak ismi birkaç kere tekrarlanır. Son olarak bir kız çocuğu gelir ve fincanlara çay doldurur. Bu videoda evin bir mekanı olan mutfağın, hangi eşya ve gereçlerden oluştuğu gösterilmektedir. Mutfağın genel anlamıyla yemek yapmaya ve yemek yemeye yönelik bir alan olduğu ve buna yönelik eşyalarla donatıldığı çocuk izleyicilere anlatılmaktadır. Çocukların nesneleri, yaşadıkları çevreyi ve evlerini algılayabilmeleri açısından TuTiTuTV'nin çok farklı videoları bulunmaktadır.

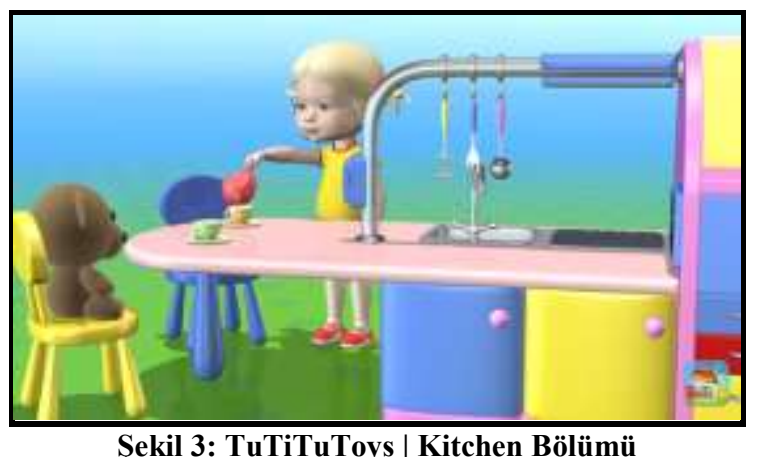

Üçüncü ve son incelenen video ise "DreamWorks TV" kanalında yer alan ColossalQuestions (Devasa Sorular) kategorisindeki "Is a Tomato a Fruitor a Vegetable?" (Domates meyve mi, sebze mi? isimli videodur (bkz. Şekil 4). $\mathrm{Bu}$ videonun da eğitici bir içeriğe sahip olduğunu söyleyebilmek mümkündür. Videoda dıș ses bulunmakta ve sohbet havasında domates hakkında bilgi vermektedir. Bilim insanlarının meyve ve sebzeye yönelik açıklamaları aktarılırken, tohumunu içerisinde barındıran bitkilerin "meyve" olduğuna vurgu yapılmaktadır. Ancak genel kanının sebze olduğu ifade edilmektedir. Video içeriğine bakıldığı zaman bilimsel bir öğretinin sade ve anlaşılır görseller kullanılarak aktarıldığını, akılda kalıcı olması için karşılaştırmalara yer verildiğini ve tüm bu kurgunun çizgi film efektleriyle yapıldığını ifade edebiliriz. Özellikle yanlış bilinen bir gerçeği düzeltebilmeye yönelik içerik üretiminde eğlenceli anlatımın yanı sıra, akılda kalıcı görsellere yer vermek de önem arz etmektedir. Bu doğrultuda domatesin neden meyve değil de sebze olarak anıldığı, çeşitli örnekler ile açıklanmaya çalışılmıştır (tarihsel kurgu, domatesin ana yemek olamayacağı ve buna bağlı olarak sadece ana yemeğe katk1 sağlayan besin olabileceği gibi).Domates üzerinden gerçekleştirilen bu videoda aynı zamanda sebze ve meyvenin farklılıkları çocuk izleyicilere anlatılmaya çalışılmaktadır. Yedikleri besinlerin hangi sınıfa ait olduklarını bilmeleri için açıklayıcı bilgiler verilmektedir. Videoda ayrıca çocuklara 
bilimsel bilginin önemi de vurgulanmaktadır. Günlük yaşamda doğru olduğu düşünülen bilgilerin (domatesi sebze olarak bilmek), bilimsel veriler ile doğru olmadığının (domatesin sebze değil meyve olması) ispat edilebileceği anlatılmaktadır.

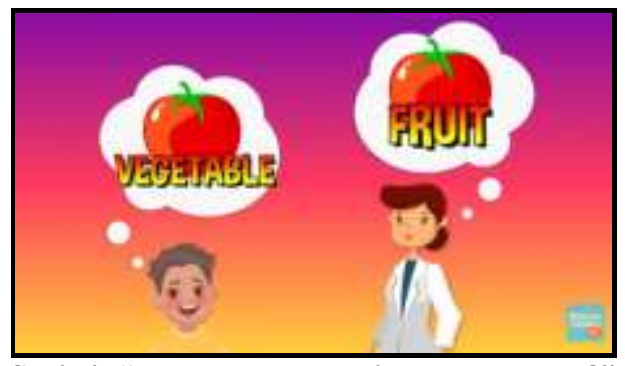

Şekil 4: "Is a Tomato a Fruitor a Vegetable?"

\section{Sonuç ve Değerlendirme}

Yeni medyanın gelişim göstermesiyle birlikte birçok alanda köklü değişimler yaşanmaya başlamıştır. Uzun yıllardır kullanılan geleneksel medyanın yerini almaya başlayan yeni medya ile birlikte gazete, dergi, radyo ve televizyon gibi kitle iletişim araçları evrim geçirmeye başlamış ve çehrelerini değiştirmiştir. Bilgisayar, internet ve sayısal teknolojilerin varlığı yeni bir yayıncılık anlayışının doğmasını sağlamıştır.

Yeni medyanın geleneksel medyaya oranla birtakım avantajları bulunmaktadır. Öncelikle yeni medya, geleneksel medyaya oranla düşük maliyetlidir. İnternet aracılığıyla herkes kendi yayınını oluşturabilmektedir. Etkileşim olgusu yeni medyada açık bir şekilde gücünü hissettirmektedir. Yani kullanıcılar hem üretici, hem de tüketici durumundadırlar. Birbirlerini eşit ölçüde etkileyecek potansiyelleri mevcuttur. Yeni medya ile birlikte yayıncılık daha hızlı bir konuma ulaşmıştır. Aynı zamanda kullanıcılar diledikleri içerikleri seçebilme hakkına ulaşmışlardır. Yeni medya hedef kitlenin daha doğru bir şekilde saptanması noktasında önemli bir role sahiptir.

Yeni medyanın avantajları olduğu gibi dezavantajları da bulunmaktadır. Bu dezavantajlardan özellikle Z Kuşağı daha yoğun şekilde etkilenmektedir. Şüphesiz ki hızla gelişen teknolojiye bu kuşak daha hızlı adapte olmaktadır. 2000 ve sonrası doğan nesil olarak adlandırılan Z Kuşağı aynı zamanda dijital yerli statüsünde değerlendirilebilmektedir. Yetişkinlere oranla teknolojiye daha hâkim olan, sosyal paylaşım ağlarını son derece etkin olarak kullanan bu kuşak, internet ortamında birtakım zararlı içeriklere de maruz kalabilmektedir.

Özellikle çocuklar yeni medya karşısında daha savunmasız olmakla birlikte, kendilerine gönderilen içerikler karşısında farkındalık oluşturamamaktadırlar. Gerek Türkiye'nin, gerekse de dünyanın en çok tıklanan video paylaşım sitesi olan YouTube ise yeni medyanın kazandırdığı en önemli mecralardan biridir. Herkesin yayıncı olmasına imkân tanıyan YouTube, tamamen kullanics odaklı bir zemine oturtulmuştur. Üye olan kullanıcılar birbirlerinin kanallarına abone olabilmekte, paylaşılan içerikleri seyredebilmekte, yorum yapabilmektedir. YouTube'ye üye olan kullanıcılar telif hakkı ve kullanım koşulları sözleşmesine onay vermek durumundadırlar. Aksi takdirde herhangi bir video yükleme işlemi gerçekleştirememektedirler. Şiddet, reklam, suç sayılacak içeriklerle, pornografik öğelerin yüklenmesine hiçbir şekilde izin verilmemektedir. Ancak bazı videolarda dolaylı olarak bu tür içeriklerle karşılaşabilmek mümkündür. $\mathrm{Bu}$ nedenle özellikle ebeveynlerin denetimi giderek zorlaşmaktadır. YouTube'nin komplike yapısı da ailelerin içerikler karşısında zafiyete düşmelerine neden olmaktadır. Özellikle $\mathrm{Z}$ kuşağının bu noktada zararlı içeriklerle karşılaşabildiğini söylemek mümkündür. Çocuklar risk grubuna yer almaktadırlar.

YouTube zararlı içeriklerin önüne geçilebilmesi, çocukların bu içeriklerden etkilenmemesi ve ailelerin daha kolay bir şekilde denetim sağlayabilmesini gerçekleştirebilmek adına YouTube Kids projesini hayata geçirmiştir. YouTube Kids; Google Play ve Apple Store'lerdan yüklenebilmektedir. Özellikle çocuklara yönelik eğitici ve öğretici içeriklerin yer alması YouTube Kids'i farklı kılmaktadır. Çocuk ve çizgi film kanallarının varlığı uygulama içerisinde göze çarpmaktadır. Platformun içeriğinin tamamen çocuklara yönelik olması ve zararlı olabilecek içeriklerden arındırılmış olması nedeniyle YouTube Kids projesinin ebeveynler açısından çocukların denetimine yönelik büyük kolaylık sağladığını ifade edebilmekteyiz. Nitekim bu sonuca platform üzerinden yayınlanan içeriklerin eğitici ve öğretici nitelikte olduklarından varılabilmektedir.

Yalnızca çocuklara yönelik içeriklerin var olduğu uygulama aracılığıyla çocuklar güvenli bir şekilde video arayabilmekte, eğitici video, müzik ve ailelere özgü programları da seyredebilmektedirler. DreamWorksTV, Sesame Street TV, TuTiTu TV ve National Geographic Kids en çok izlenen kanallar arasında yer almaktadır. YouTube Kids, çocukların aramalarına sınır getirmekte ve kontrolü ebeveynlerde toplamaktadir. Bununla birlikte tercihler ebeveynler aracılığıyla gerçekleşmektedir. Bu da dikkate değer bir diğer özelliktir. Aynı zamanda gelişim çağındaki çocukların merak duygularına cevap üretebilecek nitelikte içerikler yapılması ve bu içeriklerin öğretici kodlar ile kurgulanarak, eğlenceli videolar ile aktarılması, yeni nesil kuşağın öğrenme ve eğlenme ihtiyaçlarına yönelik verimli bir yöntem olduğu ifade edilebilmektedir.

$\mathrm{Bu}$ çalışmada "Sesame Street TV", "TuTiTuTV" ve "DreamWorks TV" aracılığıyla sunulan üç farklı video izlenmiş ve içerik analizi yöntemiyle birlikte birtakım bulgulara ulaşılmıştır. İncelenen içeriklerde eğitimin ön planda tutulduğu görülmüş ve çocukların yabancı dillerinin gelişimine katkı sağlandığı gözlemlenmiştir. Sayılar ve harflerin aktarılması da çocukların eğitim düzeylerini yükseltici etmenlerdendir. Çevresel ve zamansal kavramların öğretilmesi, birey, toplum ve doğaya yönelik bilgilerin verilmesi de göze çarpmaktadır. İnsan öğesinin merkeze konumlandırılması da YouTube Kids'in en büyük artısı durumundadir.

Görüleceği üzere YouTube Kids, yeni medya ile birlikte dönüşen yeni çocuğun birçok ihtiyacını karşılayacak düzeydedir. Aynı zamanda ebeveynlerin de çocukların izledikleri videolar karşısında denetimini sağlamıştır. YouTube Kids'in eğitici ve öğretici boyutu bu noktada oldukça önemlidir. Sürekli bilgisayar ya da akıllı 
telefonlarıyla vakit geçiren bağımlı çocuklar için YouTube Kids'in bir çözüm yolu olacağını söyleyebilmek mümkündür.

\section{Kaynakça}

Alper, A. (2012). Sosyal A ğlar. Ankara: Pelikan Yayıncılık.

Aydemir, M., Şentürk, E. E. (2016). "Yeni Medyalar ve Mesleki Eğitimin Geleceğii". Uluslararası Sosyal Araştırmalar Dergisi, 9(46), 656-663

Barbier; F.,Lavenir, C. B. (2001). Diderot'tan Internete Medya Tarihi (çev. Kerem Eksen). İstanbul: Okuyan Us Yayınevi.

Bulunmaz; B. (2015). "Yeni Medya Eski Medyaya Karşı: Savaşı Kim Kazandı Ya Da Kim Kazanacak?”. Karadeniz Teknik Üniversitesi Iletişim Araştırmaları Dergisi, 1(7), 22-29.

Dondurucu, Z. B.\& Uluçay; A. P. (2015). "Yeni Medya Ortamlarında Nefret Söylemi: Eşcinsellere Yönelik Nefret Söylemi İçeren Videoların Youtube Üzerinden İncelenmesi”. International Journal of

SocialSciencesandEducationResearch, 1(3), 875-902.

Duygulu, S. (2018). Yeni Medya Teknolojilerinin KKuşağının Ebeveynleri İle Olan İletişimine Etkisi. TRT Akademi, 3(6), 632-652.

Göztaş, A. \& Yanık, A. (2016). İletişimin Kuşaklararası Köprü Rolü, İzmir Ekonomi Üniversitesi - PERYÖN 1. Insan Kaynaklart Zirvesi

Jarvis, J. (2012). E-Sosyal Toplum; Dijital Çă̆da Sosyal Medyanın İş ve Gündelik Hayata Etkisi. (çev. Çağlar Kök), İstanbul: MediaCat Yayınları.

Kara, M. (2018). "Google'ın çocuklar için geliştirilen ilk uygulaması YouTube Kids yayında”, https://webrazzi.com/2015/02/23/google-cocukuygulamasi-youtube-kids/, Erişim Tarihi: 21.04.2018.

Livingstone, S.-Ólafsson, K. Staksrud, E. (2011). Socialnetworking, ageandprivacy. Londra, İngiltere: EU Kids Online
Mutlu, B. (2017). "Sosyal Medya Pazarlamasinin Yeni Yüzleri Youtube Içerik Üreticileri Ve Kanal Topluluklart: Youtuber - Marka İşbirliği Videolarl Üzerine Bir Araştırma”. (Yayımlanmamış yüksek lisans tezi). Ege Üniversitesi Sosyal Bilimler Enstitüsü Reklamcılık Anabilim Dalı, İzmir.

Mirzoeff, N.(1999). An Introductionto Visual Culture, London: RoutledgePub.

Scolari, C. A.(2009). "Mapping Conversations About New Media: TheTheoretical Field of Digital Communication", New Media and Society, 11(6), 943-964.

Stone, P. J.,Dunphy, D. C., Smith, M. S., Ogilvi; D. M. (1966). The General Inquirer: A Computer Approachto Content Analysis. Massachusetts: The M.I.T. Press.

Simonsen,T.M.(2011).“Categorising YouTube”. Medie Kultur, 51, 72-93.

Şahin; M. \& Şahin; G. (2016). "Yeni Medya ve Canlı Yayınlar.". Yeni Medya, 1, 50-63.

Şirin, M. R. (1999). Gösteri Çăğ Çocukları. İstanbul: İz Yayınları.

Tan, L.,Ng, S. H., Omar, A., \&Karupaiah, T. (2018). What's on YouTube A Case Study on Food and Beverage Advertising in Videos Targeted at Children on Social Media. Childhood Obesity, 14(5), 280-290.

Toffler, A. (1980). The Third Wave. (Vol. 484), New York: BantamBooks.

Törenli, N. (2005). Yeni Medya ve Yeni İletişim Ortamı. Ankara: Bilim ve Sanat Yayınları.

Türk, G. D. (2013). “Demokrasinin Dördüncü Kuvveti Yeni Medya Teknolojileri”. XVIII. Türkiye'de Internet Konferansi, İNETD 2013, 55-60.

Yegen, C. (2018). Doğru Haber Alma Hakkı ve Sosyal Medya Dezenformasyonunu Doğruluk Payı ve Yalansavar ile Tartışmak. Erciyes Illetişim Dergisi, 5(4), 101-121.

Ying, H. (2007). Youtube. (çev. İlker Şahin), İstanbul: Pegasus Yayınları

Yüksel, O. (2014). Internet Gazeteciliği ve Blog Yazarliğl Ankara: Sinemis Yayın Grup.

YouTube Kids (2018). https://kids.youtube.com/, Erişim Tarihi:

23.04.2018 